Article

\title{
Trinuclear Co(II) and Mononuclear Ni(II) Salamo-Type Bisoxime Coordination Compounds
}

\author{
Xiao-Yan Li, Quan-Peng Kang, Ling-Zhi Liu, Jian-Chun Ma and Wen-Kui Dong * \\ School of Chemical and Biological Engineering, Lanzhou Jiaotong University, Lanzhou 730070, China; \\ L1401569787@163.com (X.-Y.L.); KQpeng2580@163.com (Q.-P.K.); 1lz1009663202@126.com (L.-Z.L.); \\ majc0204@126.com (J.-C.M.) \\ * Correspondence: dongwk@126.com; Tel.: +86-931-4938-703
}

Received: 19 December 2017; Accepted: 15 January 2018; Published: 17 January 2018

\begin{abstract}
One trinuclear $\mathrm{Co}(\mathrm{II})$ coordination compound $\left[\left\{\mathrm{CoL}^{1}(\mathrm{OAc})\left(\mathrm{CH}_{3} \mathrm{COCH}_{3}\right)\right\}_{2} \mathrm{Co}\right](\mathbf{1})$ and one unprecedented mononuclear $\mathrm{Ni}(\mathrm{II})$ coordination compound $\left[\mathrm{Ni}\left(\mathrm{L}^{2}\right)_{2}\right](2)$, constructed from a Salamo-type ligand $\mathrm{H}_{2} \mathrm{~L}^{1}$ were synthesized and characterized by elemental analyses, IR, UV-vis spectra, and single crystal $\mathrm{X}$-ray diffraction analyses. The results show that the $\mathrm{Co}$ (II) atoms have no significant distortion in $\mathrm{CoO}_{6}$ or $\mathrm{CoO}_{4} \mathrm{~N}_{2}$ octahedrons in coordination compound 1. Interestingly, in coordination compound 2, the desired tri- or mono-nuclear Salamo-type Ni(II) coordination compound was not obtained, but an unprecedented $\mathrm{Ni}(\mathrm{II})$ coordination compound $\left[\mathrm{Ni}\left(\mathrm{L}^{2}\right)_{2}\right]$ was synthesized, the Ni1 atom having no significant distortion in the $\mathrm{NiO}_{2} \mathrm{~N}_{2}$ planar quadrilateral geometry. Furthermore, the antimicrobial activities of coordination compound $\mathbf{1}$ and previously reported coordination compound $\left[\left\{\mathrm{CoL}^{1}(\mathrm{OAc})(\mathrm{MeOH})\right\}_{2} \mathrm{Co}\right] \cdot 2 \mathrm{MeOH}(3)$ are discussed.
\end{abstract}

Keywords: Salamo-type bisoxime; $\mathrm{Co}(\mathrm{II})$ and $\mathrm{Ni}(\mathrm{II})$ coordination compounds; fluorescence property; antimicrobial property

\section{Introduction}

$\mathrm{N}_{2} \mathrm{O}_{2}$-type chelating ligands and their metal coordination compounds have achieved considerable attention in inorganic chemistry over several decades [1-3], especially in the area of their potential application in catalysts [4,5], biological fields [6-10], electrochemical conducts [11], ion recognitions [12-16], supramolecular architecture [17-20], as well as magnetic [21-24] and luminescence [25,26] materials. Recently, a new $\mathrm{N}_{2} \mathrm{O}_{2}$-type analogue, the Salamo ligand was developed [27-32]. Interestingly, other works have contributed to researching mono-, multi-, homo- or heteromultinuclear metal coordination compounds having Salamo-type ligands or their derivatives [33-35].

Herein, we designed and synthesized two $\mathrm{Co}(\mathrm{II})$ and $\mathrm{Ni}(\mathrm{II})$ coordination compounds: [ $\left.\left\{\mathrm{CoL}^{1}(\mathrm{OAc})\left(\mathrm{CH}_{3} \mathrm{COCH}_{3}\right)\right\}_{2} \mathrm{Co}\right](\mathbf{1})$ and $\left[\mathrm{Ni}\left(\mathrm{L}^{2}\right)_{2}\right](2)$. Furthermore, a previously reported coordination compound $\left[\left\{\mathrm{CoL}^{1}(\mathrm{OAc})(\mathrm{MeOH})\right\}_{2} \mathrm{Co}\right] \cdot 2 \mathrm{MeOH}(3)$ was synthesized [36]. Compared with the previously reported coordination compounds [36-49], coordination compounds $\mathbf{1}$ and $\mathbf{3}$ with a similar structure are both symmetrically trinuclear. The content of these previous works is mainly based on the study of solvent effect and fluorescence properties. In this paper, not merely the fluorescence properties were studied but also the most important discovery was to find coordination compounds $\mathbf{1}$ and $\mathbf{3}$ have good antimicrobial activities. This study provides a new idea for the application of such Salamo-type coordination compounds. Interestingly, catalysis of $\mathrm{Ni}$ (II) ions gives rise to unexpected cleavage of two $\mathrm{N}-\mathrm{O}$ and two $\mathrm{C}-\mathrm{C}$ bonds in $\mathrm{H}_{2} \mathrm{~L}^{1}$ and an unprecedented mono-nuclear $\mathrm{Ni}(\mathrm{II})$ coordination compound has been discovered; this catalytic phenomenon of $\mathrm{Ni}(\mathrm{II})$ ions is a first for the previously reported Salamo Ni(II) coordination compounds. 


\section{Experimental}

\subsection{Materials and Methods}

5-Chlorosalicylaldehyde (98\%) was purchased from Alfa Aesar (New York, NY, USA) and was used without further purification. 1,3-Dibromoprophane, other reagents and solvents were analytical grade reagents from Tianjin Chemical Reagent Factory.

Carbon, hydrogen, and nitrogen analyses were obtained using a GmbH VariuoEL V3.00 automatic elemental analysis instrument (Berlin, Germany). Elemental analyses for $\mathrm{Co}$ (II) or Ni(II) were detected with an IRIS ER/S-WP-1 ICP atomic emission spectrometer (Berlin, Germany). Melting points were obtained by the use of a microscopic melting point apparatus made by Beijing Taike Instrument Company Limited (Beijing, China) and were uncorrected. IR spectra $\left(400-4000 \mathrm{~cm}^{-1}\right)$ were recorded on a Vertex 70 FT-IR spectrophotometer (Bruker, Billerica, MA, USA), with samples prepared as $\mathrm{KBr}$ pellets. UV-vis absorption spectra were recorded on a Shimadzu UV-3900 spectrometer (Shimadzu, Japan). ${ }^{1} \mathrm{H}$ NMR spectra were determined by German Bruker AVANCE DRX-400/600 spectroscopy (Bruker AVANCE, Billerica, MA, USA). X-ray single crystal structure determinations for coordination compounds 1 and $\mathbf{2}$ were carried out on a Bruker Smart Apex CCD (Bruker AVANCE, Billerica, MA, USA) and SuperNova Dual (Cu at zero) Eos four-circle diffractometer. Fluorescence spectra were recorded on a F-7000 FL spectrophotometer (Hitachi, Tokyo, Japan). Antimicrobial experiments were carried out using a SW-CJ (Standard Type), LDZX-50KBS Vertical Pressure Steam Sterilizer made by Boyn Instrument Company Limited (Hangzhou, China), YCP-100P Microbiological incubator made by Guangzhou Fangtong Biotechnology Company Limited (Guangzhou, China).

\subsection{Synthesis of $\mathrm{H}_{2} L^{1}$}

The ligand 4,4'-dichloro-2,2'-[(propane-1,3-diyldioxy)bis(nitrilomethylidyne)]diphenol $\left(\mathrm{H}_{2} \mathrm{~L}^{1}\right)$ was synthesized in accordance with a similar method reported earlier $[44,48,50]$. (Scheme 1) Yield: 75.8\%. m.p. ${ }^{164-166}{ }^{\circ} \mathrm{C} .{ }^{1} \mathrm{H}$ NMR $\left(400 \mathrm{MHz}, \mathrm{CDCl}_{3}\right), \delta 2.14\left(\mathrm{t}, J=6.0 \mathrm{~Hz}, 2 \mathrm{H}, \mathrm{CH}_{2}\right), 4.31(\mathrm{t}, J=6.0 \mathrm{~Hz}$, $\left.4 \mathrm{H}, \mathrm{CH}_{2}\right), 6.85(\mathrm{~d}, J=8.0 \mathrm{~Hz}, 2 \mathrm{H}, \mathrm{ArH}), 7.25(\mathrm{~s}, 2 \mathrm{H}, \mathrm{ArH}), 7.33(\mathrm{~d}, J=8.0 \mathrm{~Hz}, 2 \mathrm{H}, \mathrm{ArH}), 8.09(\mathrm{~s}, 2 \mathrm{H}$, $\mathrm{CH}=\mathrm{N}), 9.80(\mathrm{~s}, 2 \mathrm{H}, \mathrm{OH}) . \mathrm{IR}\left(\mathrm{KBr}, \mathrm{cm}^{-1}\right): 3101[v(\mathrm{O}-\mathrm{H})], 1606[v(\mathrm{C}=\mathrm{N})], 1263$ [v(Ar-O)]. UV-Vis $\left(\mathrm{CH}_{3} \mathrm{OH}\right), \lambda_{\max }(\mathrm{nm})\left(\varepsilon_{\max }\right): 220,265$ and $323 \mathrm{~nm}\left(2.5 \times 10^{-5} \mathrm{M}\right)$. Anal. Calcd. for $\mathrm{C}_{17} \mathrm{H}_{16} \mathrm{Cl}_{2} \mathrm{~N}_{2} \mathrm{O}_{4}(\%)$ : C 53.02; H 4.11; N 7.45. Found: C 53.28; H 4.21; N 7.31.

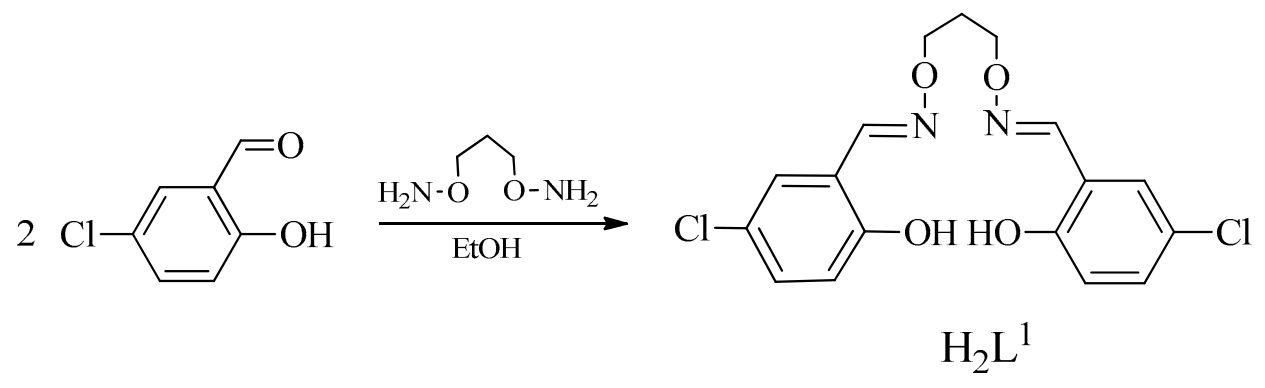

Scheme 1. Synthetic route to $\mathrm{H}_{2} \mathrm{~L}^{1}$.

\subsection{Syntheses of Coordination Compounds $\mathbf{1}, \mathbf{2}$, and $\mathbf{3}$}

Tri- and mono-nuclear coordination compounds 1, 2, and $\mathbf{3}$ were synthesized via the reaction of $\mathrm{Co}(\mathrm{OAc})_{2}$ and $\mathrm{Ni}(\mathrm{OAc})_{2}$ with $\mathrm{H}_{2} \mathrm{~L}^{1}$, respectively (Scheme 2). 


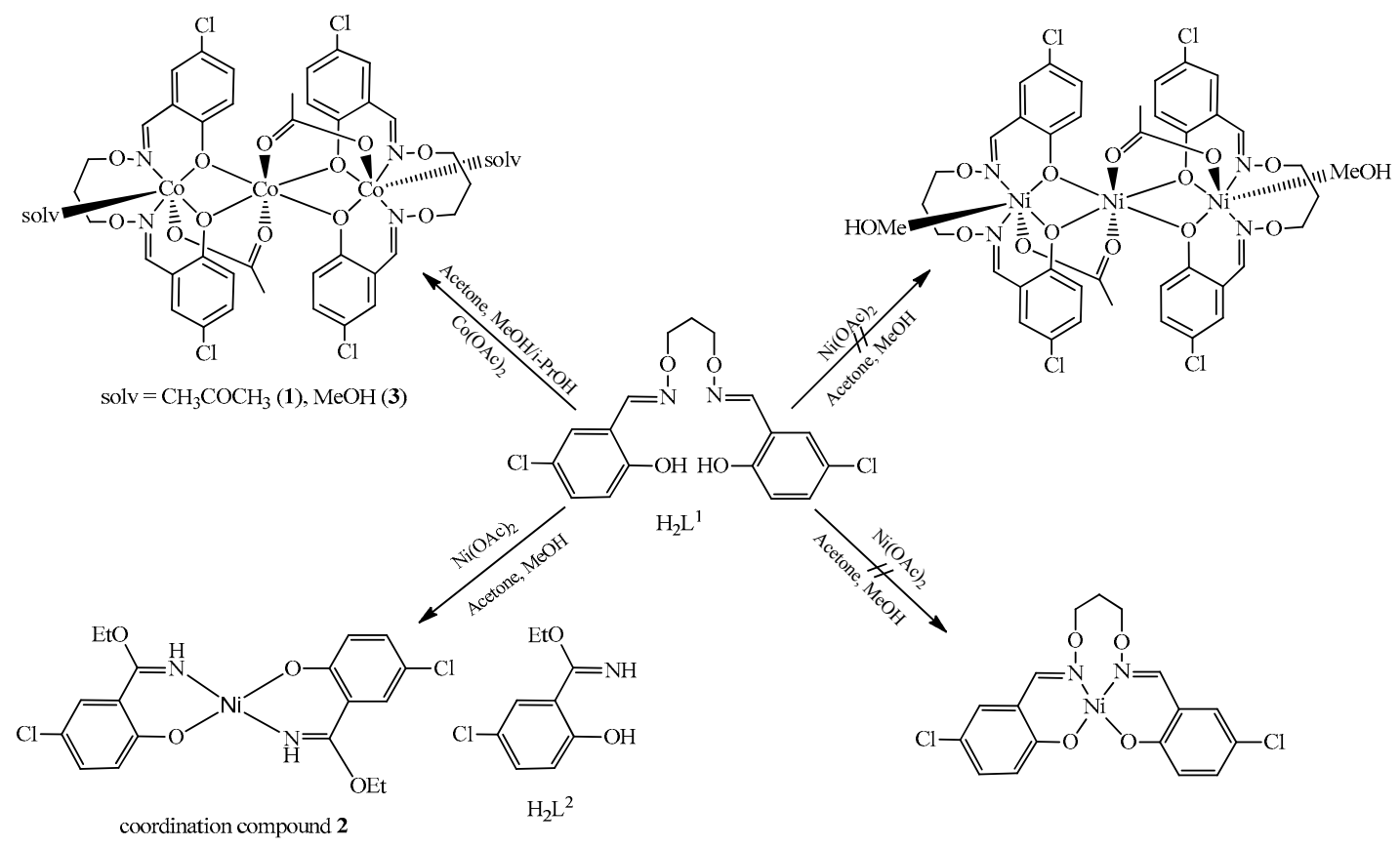

Scheme 2. Syntheses of coordination compounds 1, 2, and 3.

\subsubsection{Synthesis of Coordination Compound 1}

To an isopropanol solution $(2 \mathrm{~mL})$ of cobalt(II) acetate tetrahydrate $(3.72 \mathrm{mg}, 0.015 \mathrm{mmol})$, a solution of $\mathrm{H}_{2} \mathrm{~L}^{1}(3.83 \mathrm{mg}, 0.010 \mathrm{mmol})$ in acetone $(3 \mathrm{~mL})$ was added dropwise, the mixed solution color changed to brown instantly, and stirring was continued for $20 \mathrm{~min}$. With the gradual diffusion of solvent, several brown block crystals were obtained after three weeks on slow evaporation of the mixture solution in open atmosphere.

\subsubsection{Synthesis of Coordination Compound 2}

To a solution $(3 \mathrm{~mL})$ of nickel(II) acetate tetrahydrate $(5.07 \mathrm{mg}, 0.015 \mathrm{mmol})$ in methanol was added dropwise $\mathrm{H}_{2} \mathrm{~L}^{1}(3.83 \mathrm{mg}, 0.010 \mathrm{mmol})$ in acetone $(2 \mathrm{~mL})$ and then stirred for $20 \mathrm{~min}$. With the gradual diffusion of solvent, several green block single crystals were obtained after two weeks on slow evaporation of the solution in open atmosphere. Several green block crystals suitable for X-ray crystallography were collected and then filtered and washed with n-hexane.

\subsubsection{Synthesis of Coordination Compound 3}

Coordination compound 3 was synthesized according to the same method reported earlier [36].

Coordination compound 1, light brown blocks. Yield, $3.05 \mathrm{mg}(51.9 \%)$. IR $\left(\mathrm{KBr}, \mathrm{cm}^{-1}\right)$ : $1616[v(\mathrm{C}=\mathrm{N})], 1205[v(\mathrm{Ar}-\mathrm{O})] . \mathrm{UV}-\mathrm{Vis}\left(\mathrm{CH}_{3} \mathrm{OH}\right), \lambda_{\max }(\mathrm{nm})\left(\varepsilon_{\max }\right): 230$ and $367 \mathrm{~nm}\left(2.5 \times 10^{-5} \mathrm{M}\right)$. Anal. Calcd. for $\mathrm{C}_{44} \mathrm{H}_{46} \mathrm{Cl}_{4} \mathrm{Co}_{3} \mathrm{~N}_{4} \mathrm{O}_{14}(\%)$ : C, 45.04; H, 3.95; N, 4.77; $\mathrm{Co}$, 15.07. Found: $\mathrm{C}, 45.10 ; \mathrm{H}, 4.18$; $\mathrm{N}, 4.59 ; \mathrm{Co}, 15.09$.

Coordination compound 2, light green blocks. Yield, $2.75 \mathrm{mg}(60.3 \%)$. IR $\left(\mathrm{KBr}, \mathrm{cm}^{-1}\right)$ : $1626[v(\mathrm{C}=\mathrm{N})], 1254[v(\mathrm{Ar}-\mathrm{O})]$. UV-Vis $\left(\mathrm{CH}_{3} \mathrm{OH}\right), \lambda_{\max }(\mathrm{nm})\left(\varepsilon_{\max }\right): 232$ and $364 \mathrm{~nm}\left(2.5 \times 10^{-5} \mathrm{M}\right)$. Anal. Calcd. for $\mathrm{C}_{18} \mathrm{H}_{18} \mathrm{Cl}_{2} \mathrm{~N}_{2} \mathrm{NiO}_{4}(\%)$ : C, 47.42; H, 3.98; N, 6.14; Ni, 12.87. Found: $\mathrm{C}, 47.46 ; \mathrm{H}, 4.05$; $\mathrm{N}, 6.07 ; \mathrm{Ni}, 12.81$.

\subsection{Crystal Structures of Coordination Compounds $\mathbf{1}$ and $\mathbf{2}$}

A crystal diffractometer provides a monochromatic beam of Mo K $\alpha$ radiation $(0.71073 \AA$ ) produced from a sealed Mo X-ray tube using a graphite monochromator and was used for obtaining crystal 
data for coordination compounds 1 and 2 at 293(2) and 294.29(10) K, respectively. The LP factor and semi-empirical absorption were applied using the SADABS program. The structures of coordination compounds $\mathbf{1}$ and $\mathbf{2}$ were solved by direct methods (SHELXS-2014) [51], and $\mathrm{H}$ atoms were included at the calculated positions and constrained to ride on their parent atoms. All the non-hydrogen atoms were refined anisotropically using a full-matrix least-squares procedure on $F^{2}$ with SHELXL-2014 [52]. Crystal data and experimental parameters relevant to the structure determinations are given in Table 1.

Table 1. Crystallographic data and refinement parameters for coordination compounds $\mathbf{1}$ and 2.

\begin{tabular}{|c|c|c|}
\hline Coordination Compound & 1 & 2 \\
\hline Formula & $\mathrm{C}_{44} \mathrm{H}_{46} \mathrm{Cl}_{4} \mathrm{Co}_{3} \mathrm{~N}_{4} \mathrm{O}_{14}$ & $\mathrm{C}_{18} \mathrm{H}_{18} \mathrm{Cl}_{2} \mathrm{~N}_{2} \mathrm{NiO}_{4}$ \\
\hline Formula weight & 1173.44 & 455.95 \\
\hline Temperature (K) & 293(2) & $294.29(10)$ \\
\hline Wavelength (̊) & 0.71073 & 0.71073 \\
\hline Crystal system & triclinic & monoclinic \\
\hline Space group & $P-1$ & $P 2_{1} / \mathrm{c}$ \\
\hline$a(\AA)$ & $9.6429(13)$ & $26.642(2)$ \\
\hline$b(\AA)$ & $11.4136(15)$ & $5.0020(4)$ \\
\hline$c(\AA)$ & $12.5954(17)$ & 13.8504(14) \\
\hline$\alpha\left({ }^{\circ}\right)$ & $99.797(2)$ & 90 \\
\hline$\beta\left(^{\circ}\right)$ & $106.340(2)$ & $92.278(9)$ \\
\hline$\gamma\left({ }^{\circ}\right)$ & $104.907(2)$ & 90 \\
\hline$V\left(\AA^{3}\right)$ & $1240.7(3)$ & 1844.3(3) \\
\hline Z & 1 & 4 \\
\hline$D_{\text {calc }}\left(\mathrm{g} \cdot \mathrm{cm}^{-3}\right)$ & 1.570 & 1.642 \\
\hline$\mu\left(\mathrm{mm}^{-1}\right)$ & 1.274 & 1.369 \\
\hline$F(000)$ & 599 & 936 \\
\hline Crystal size (mm) & $0.18 \times 0.22 \times 0.25$ & $0.04 \times 0.05 \times 0.14$ \\
\hline$\theta$ Range $\left(^{\circ}\right)$ & $1.75-25.008$ & $3.372-26.022$ \\
\hline \multirow{3}{*}{ Index ranges } & $-11 \leq h \leq 8$ & $-32 \leq h \leq 32$ \\
\hline & $-13 \leq k \leq 13$ & $-6 \leq k \leq 6$ \\
\hline & $-14 \leq l \leq 14$ & $-16 \leq l \leq 17$ \\
\hline Reflections collected & 6937 & 3674 \\
\hline Independent reflections & 4359 & 1808 \\
\hline Rint & 0.0175 & 0.0584 \\
\hline Completeness to $\theta$ & $99.5 \%(\theta=25.01)$ & $99.7 \%(\theta=25.242)$ \\
\hline Data/restraints/parameters & $4359 / 0 / 316$ & $1808 / 0 / 129$ \\
\hline GOF & 1.046 & 1.017 \\
\hline Final $R_{1}, w R_{2}$ indices & $0.0376,0.1038$ & $0.0526,0.0882$ \\
\hline $\mathrm{R}_{1}{ }^{a}, \mathrm{wR}_{2}{ }^{b}$ indices (all data) & $0.0429,0.1096$ & $0.0899,0.1105$ \\
\hline Largest differences peak and hole $\left(\mathrm{e} \AA^{-3}\right)$ & $0.844 /-0.478$ & $0.449 /-0.368$ \\
\hline
\end{tabular}

Crystallographic data were deposited with the Cambridge Crystallographic Data Centre as supplementary publication, No. CCDC 1812269, 1812270 and 1812268 for coordination compounds 1, 2, and 3. Copies of the data can be obtained free of charge on application to CCDC, 12 Union Road, Cambridge CB21EZ, UK (Telephone: (44) 01223 762910; Fax: +44-1223-336033; E-mail: deposit @ccdc.cam.ac.uk). These data can be also obtained free of charge at www.ccdc.cam.Ac.uk/conts/retrieving.html.

\section{Results and Discussion}

\subsection{IR Spectra}

The IR spectra of $\mathrm{H}_{2} \mathrm{~L}^{1}$ and coordination compounds $\mathbf{1}$ and $\mathbf{2}$ show various absorption bands (Figure 1). A characteristic band of $\mathrm{C}=\mathrm{N}$ stretching vibrations of the free ligand $\mathrm{H}_{2} \mathrm{~L}^{1}$ appears at $1606 \mathrm{~cm}^{-1}$, which is shifted to 1616 and $1626 \mathrm{~cm}^{-1}$ in the spectra of coordination compounds 1 and 2 , 
respectively [53-55]. This indicates that the $\mathrm{Co}(\mathrm{II})$ and $\mathrm{Ni}(\mathrm{II})$ atoms are coordinated with azomethine nitrogen atoms of deprotonated $\left(\mathrm{L}^{1}\right)^{2-}$ and $\left(\mathrm{L}^{2}\right)^{-}$units [56,57]. An $\mathrm{Ar}-\mathrm{O}$ stretching band emerges at $1263 \mathrm{~cm}^{-1}$ in the IR spectrum of the free ligand $\mathrm{H}_{2} \mathrm{~L}^{1}$, while those of coordination compounds 1 and 2 appear at 1205 and $1254 \mathrm{~cm}^{-1}$, respectively. The Ar-O stretching bands are shifted to lower frequencies, which can be evidence of the coordination of phenolic oxygen atoms to the $\mathrm{Co}(\mathrm{II})$ and $\mathrm{Ni}(\mathrm{II})$ atoms [58,59]. The free ligand $\mathrm{H}_{2} \mathrm{~L}^{1}$ shows an expected absorption band at $3101 \mathrm{~cm}^{-1}$ and a sharp absorption band emerges at $3361 \mathrm{~cm}^{-1}$ in coordination compound 2, which indicates that the phenolic groups of the ligand have been deprotonated in the case of coordination compound $\mathbf{1}[60,61]$, while the N-H bond exists in coordination compound 2 .

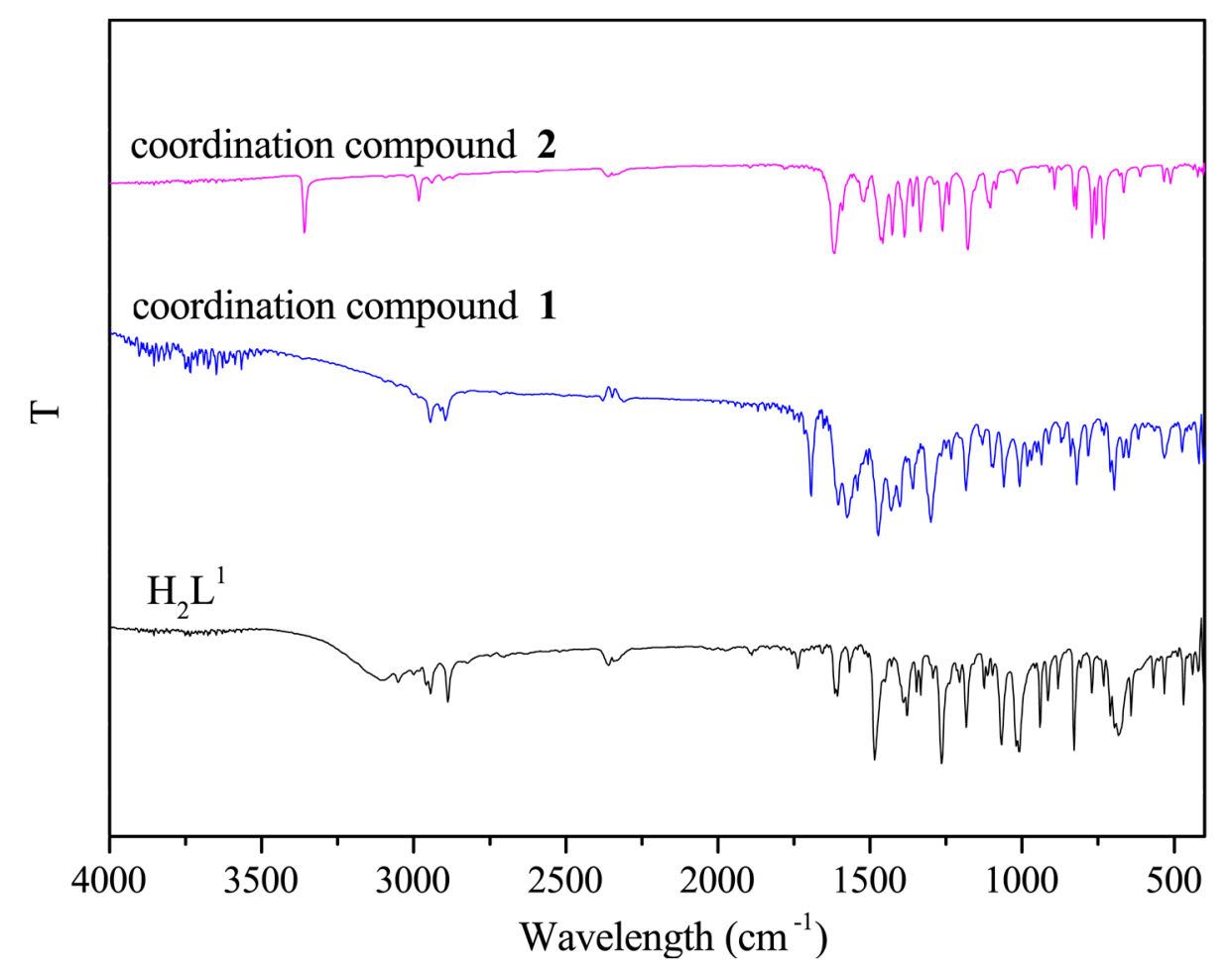

Figure 1. Infrared spectra of $\mathrm{H}_{2} \mathrm{~L}^{1}$ and its coordination compounds $\mathbf{1}$ and 2.

\subsection{UV-Vis Spectra}

UV-vis spectra of $\mathrm{H}_{2} \mathrm{~L}^{1}$ and coordination compounds 1 and 2 are presented in Figure 2. The absorption spectrum of $\mathrm{H}_{2} \mathrm{~L}^{1}$ exhibits three absorption peaks at ca. 220, 265, and $323 \mathrm{~nm}$, the former two peaks could be attributed to the $\pi-\pi^{*}$ type transitions of the benzene rings, the later peak at $323 \mathrm{~nm}$ is assigned to the $\pi-\pi^{*}$ transitions of the $\mathrm{C}=\mathrm{N}$ bonds and conjugated aromatic chromophore $[62,63]$. Compared to the absorption peaks of the free ligand $\mathrm{H}_{2} \mathrm{~L}^{1}$, the first absorption peaks are observed at 230 and $235 \mathrm{~nm}$ in coordination compounds $\mathbf{1}$ and 2, respectively. These peaks are bathochromically shifted, indicating coordination of the $\left(\mathrm{L}^{1}\right)^{2-}$ and $\left(\mathrm{L}^{2}\right)^{-}$moieties with the $\mathrm{Co}(\mathrm{II})$ and $\mathrm{Ni}(\mathrm{II})$ atoms. The other two peaks at ca. 265 and $323 \mathrm{~nm}$ have disappeared in coordination compounds 1 and 2. Meanwhile, new peaks emerge at ca. 367 and $364 \mathrm{~nm}$ in coordination compounds 1 and 2, respectively, which belong to the $n-\pi^{*}$ charge transfer transitions from the lone-pair electrons of the $\mathrm{N}$ atoms of $\mathrm{C}=\mathrm{N}$ groups $[64,65]$.

\subsection{Description of the Crystal Structures}

Selected bond lengths and angles for coordination compounds $\mathbf{1}$ and $\mathbf{2}$ are listed in Table 2, respectively. The corresponding hydrogen bonds of coordination compound $\mathbf{1}$ are summarized in Table 3. 


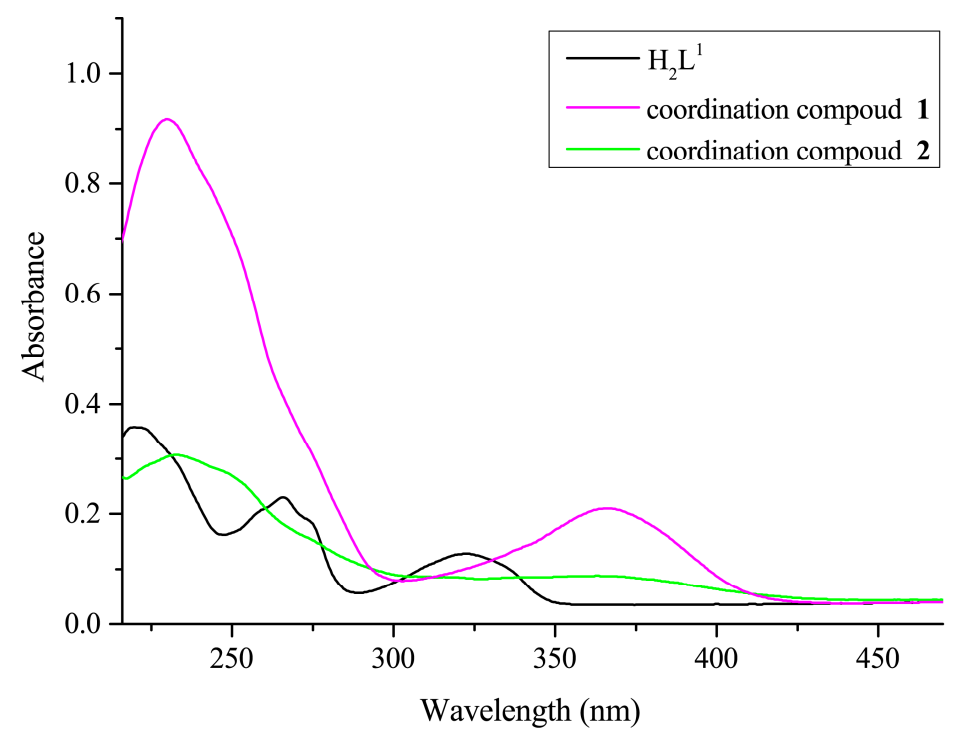

Figure 2. UV-vis spectra of $\mathrm{H}_{2} \mathrm{~L}^{1}$ and coordination compounds $\mathbf{1}$ and 2 in methanol $\left(\mathrm{c}=2.5 \times 10^{-5} \mathrm{M}\right)$.

Table 2. Selected bond lengths $(\AA)$ and angles $\left(^{\circ}\right)$ of coordination compounds $\mathbf{1}$ and 2.

\begin{tabular}{|c|c|c|c|}
\hline \multicolumn{4}{|c|}{ Coordination Compound 1} \\
\hline Bond & Lengths & Bond & Lengths \\
\hline Co1-O1 & $2.0948(17)$ & $\mathrm{Co} 1-\mathrm{O} 2$ & $2.1438(16)$ \\
\hline Co1-O5 & $2.0884(17)$ & Co1-O1 $\# 1$ & $2.0948(17)$ \\
\hline $\mathrm{Co} 1-\mathrm{O} 2^{\# 1}$ & $2.1437(16)$ & Co1-O5 $\# 1$ & $2.0884(17)$ \\
\hline $\mathrm{Co} 2-\mathrm{O} 1$ & $2.0756(16)$ & $\mathrm{Co} 2-\mathrm{O} 2$ & $2.0177(17)$ \\
\hline $\mathrm{Co} 2-\mathrm{O} 6$ & $2.0224(19)$ & $\mathrm{Co} 2-\mathrm{O} 7$ & $2.276(2)$ \\
\hline Co2-N1 & $2.109(2)$ & $\mathrm{Co} 2-\mathrm{N} 2$ & $2.208(2)$ \\
\hline Bond & Angles & Bond & Angles \\
\hline O1-Co1-O2 & $76.14(6)$ & O5-Co1-O1 & $88.26(7)$ \\
\hline O1-Co1-O1 $\# 1$ & 180.0 & $\mathrm{O} 1-\mathrm{Co} 1-\mathrm{O} 2^{\# 1}$ & $103.86(6)$ \\
\hline $\mathrm{O} 5^{\# 1-C o 1-O 1}$ & $91.74(7)$ & O5-Co1-O2 & $87.37(7)$ \\
\hline $\mathrm{O} 1{ }^{\# 1-C o 1-O 2}$ & $103.86(6)$ & $\mathrm{O} 2-\mathrm{Co} 1-\mathrm{O} 2^{\# 1}$ & 180.0 \\
\hline $\mathrm{O}^{\# 1}-\mathrm{Co} 1-\mathrm{O} 2$ & $92.63(7)$ & O5-Co1-O1 $\# 1$ & $91.74(7)$ \\
\hline $\mathrm{O} 5-\mathrm{Co} 1-\mathrm{O} 22^{\# 1}$ & $92.63(7)$ & O5 $\# 1-C o 1-O 5$ & 180.0 \\
\hline $\mathrm{O} 1^{\# 1}-\mathrm{Co} 1-\mathrm{O} 2^{\# 1}$ & $76.14(6)$ & $\mathrm{O} 5^{\# 1}-\mathrm{Co} 1-\mathrm{O} 1^{\# 1}$ & $88.26(7)$ \\
\hline $\mathrm{O}^{\# 1}-\mathrm{Co} 1-\mathrm{O} 2^{\# 1}$ & 87.37(7) & O2-Co2-O1 & $79.36(7)$ \\
\hline O6-Co2-O1 & $91.68(7)$ & $\mathrm{O} 1-\mathrm{Co} 2-\mathrm{O} 7$ & $99.74(8)$ \\
\hline O1-Co2-N1 & $84.64(7)$ & O1-Co2-N2 & $164.08(8)$ \\
\hline $\mathrm{O} 2-\mathrm{Co} 2-\mathrm{O} 6$ & $99.88(8)$ & $\mathrm{O} 2-\mathrm{Co} 2-\mathrm{O} 7$ & $86.31(7)$ \\
\hline $\mathrm{O} 2-\mathrm{Co} 2-\mathrm{N} 1$ & $160.21(8)$ & $\mathrm{O} 2-\mathrm{Co} 2-\mathrm{N} 2$ & $84.77(7)$ \\
\hline O6-Co2-O7 & $167.88(7)$ & O6-Co2-N1 & $92.09(8)$ \\
\hline $\mathrm{O} 6-\mathrm{Co} 2-\mathrm{N} 2$ & $89.78(9)$ & $\mathrm{N} 1-\mathrm{Co} 2-\mathrm{O} 7$ & $85.00(8)$ \\
\hline $\mathrm{N} 2-\mathrm{Co} 2-\mathrm{O} 7$ & $80.36(8)$ & N1-Co2-N2 & 111.15(8) \\
\hline \multicolumn{4}{|c|}{ Coordination Compound 2} \\
\hline Bond & Lengths & Bond & Lengths \\
\hline Ni1-O1 & $1.914(3)$ & Ni1-N1 & $1.918(4)$ \\
\hline $\mathrm{Ni1}-\mathrm{O} 1^{\# 2}$ & 1.914(3) & $\mathrm{Ni1}-\mathrm{N} 1{ }^{\# 2}$ & $1.918(4)$ \\
\hline Bond & Angles & Bond & Angles \\
\hline O1-Ni1-N1 & $92.15(15)$ & $\mathrm{O} 1{ }^{\# 2}-\mathrm{Ni1}-\mathrm{O} 1$ & 180.0 \\
\hline O1-Ni1-N1 $\# 2$ & $87.85(15)$ & $\mathrm{O} 1^{\# 2}-\mathrm{Ni1}-\mathrm{N} 1$ & $87.85(15)$ \\
\hline N1-Ni1-N1 $\# 2$ & 180.0 & $\mathrm{O} 1^{\# 2}-\mathrm{Ni} 1-\mathrm{N} 1^{\# 2}$ & $92.15(15)$ \\
\hline
\end{tabular}

Symmetry transformations used to generate equivalent atoms: ${ }^{\# 1}-x+1,-y+1,-z{ }^{\# 2}-x+1 / 2,-y+1 / 2,-z$. 
Table 3. Hydrogen bonding interactions $\left(\AA,^{\circ}\right)$ of coordination compound $\mathbf{1}$.

\begin{tabular}{|c|c|c|c|c|}
\hline D-H $\cdots A$ & D-H & $\mathbf{H} \cdots \mathbf{A}$ & D..A & D-H $\cdots A$ \\
\hline \multicolumn{5}{|c|}{ Coordination compound $\mathbf{1}$} \\
\hline $\mathrm{C} 2-\mathrm{H} 2 \cdots \mathrm{O} 2$ & 0.93 & 2.58 & $3.281(3)$ & 133 \\
\hline $\mathrm{C} 8-\mathrm{H} 8 \mathrm{~B} \cdots \mathrm{O} 7$ & 0.97 & 2.53 & $3.425(4)$ & 153 \\
\hline C10-H10B $\cdots$ O3 & 0.97 & 2.54 & $2.931(5)$ & 104 \\
\hline C10-H10B $\cdots$ O6 & 0.97 & 2.45 & $3.329(4)$ & 150 \\
\hline $\mathrm{C} 16-\mathrm{H} 16 \cdots \mathrm{O} 5$ & 0.93 & 2.48 & $3.207(3)$ & 135 \\
\hline C20-H20C $\cdots \mathrm{O} 5$ & 0.96 & 2.49 & $3.358(5)$ & 151 \\
\hline
\end{tabular}

\subsubsection{Crystal Structure of Coordination Compound 1}

The unit cell of coordination compound $\mathbf{1}$ is composed of three Co(II) atoms, two completely deprotonated $\left(\mathrm{L}^{1}\right)^{2-}$ units, two $\mu_{2}$-acetate ions, and two coordinated acetone molecules. (Figure 3) A symmetrical trinuclear $\mathrm{Co}(\mathrm{II})$ coordination compound is formed, with the $\mathrm{Co} 1$ atom occupying the center of symmetry $(1 / 2,1 / 2,1 / 2)$ and the other two $\mathrm{Co}(\mathrm{II})$ atoms $\left(\mathrm{Co} 2, \mathrm{Co}^{\# 1}\right.$, symmetry code ${ }^{(\# 1)}$ : $-\mathrm{x}+1,-\mathrm{y}+1,-\mathrm{z})$ to be related by this center of symmetry. The two $\left(\mathrm{L}^{1}\right)^{2-}$, two $\mu_{2}$-acetate ions and the two coordinated acetone molecules are also centrosymmetry related. The $\mathrm{Co}$ (II) atoms have no significant distortion in $\mathrm{CoO}_{6}$ or $\mathrm{CoO}_{4} \mathrm{~N}_{2}$ octahedrons. The two terminal $\mathrm{Co}$ (II) atom $\left(\mathrm{Co} 2\right.$ or $\left.\mathrm{Co}^{\# 1}\right)$ is hexa-coordinated with donor $\mathrm{N}_{2} \mathrm{O}_{2}$ atoms $\left(\mathrm{N} 1, \mathrm{~N} 2, \mathrm{O} 1, \mathrm{O} 2\right.$ or $\left.\mathrm{N1}^{\# 1}, \mathrm{~N}^{\# 1}, \mathrm{O}^{\# 1}, \mathrm{O}^{\# 1}\right)$, one $\mu_{2}$-phenoxo oxygen atom $\left(\mathrm{O} 2\right.$ or $\left.\mathrm{O}^{\# 1}\right)$ and the other oxygen atom $\left(\mathrm{O} 7\right.$ or $\left.\mathrm{O}^{\# 1}\right)$ comes from the coordinated acetone molecule, respectively. One axial bond of Co2-O7 is 2.276(2) $\AA$, is longer than the bond of Co2-O6 (2.0224(19) $\AA$ ). It shows that the acetate ions involved in the coordination are more stable than the coordinated acetone molecules [66]. The dihedral angle between the planes of N1-Co2-O1 and $\mathrm{N} 2-\mathrm{Co} 2-\mathrm{O} 4$ is $4.23(5)^{\circ}$, reveals the $\mathrm{Co}(\mathrm{II})$ atom $\left(\mathrm{Co} 2 \mathrm{or} \mathrm{Co}^{\# 1}\right)$ with significant distortion in the $\mathrm{CoO}_{4} \mathrm{~N}_{2}$ octahedron [67]. Meanwhile, the central Co1 atom is completed by four phenoxo oxygen atoms (O1, $\mathrm{O} 5, \mathrm{O}^{\# 1}$, and $\left.\mathrm{O}^{\# 1}\right)$ of two deprotonated $\left(\mathrm{L}^{1}\right)^{2-}$ units, two oxygen atoms $\left(\mathrm{O} 2\right.$ and $\left.\mathrm{O}^{\# 1}\right)$ from the bridging $\mu_{2}$-acetate ions, and the axial bond Co1-O5 (2.0884(16) $\AA$ ) is also shorter by $0.0064(01) \AA$ than the Co1-O1 bond (2.0948(17) $\AA$ ) and by $0.05540 \AA$ A than the Co1-O2 bond (2.1438(16) $\AA$ ). Although the $\mathrm{Co}$ (II) atoms are all hexa-coordinated, the coordination sphere of the Co1 atom consists of six oxygen atoms, and that of the $\mathrm{Co} 2\left(\mathrm{or} \mathrm{Co}^{\# 1}\right)$ atom includes two nitrogen and four oxygen atoms.
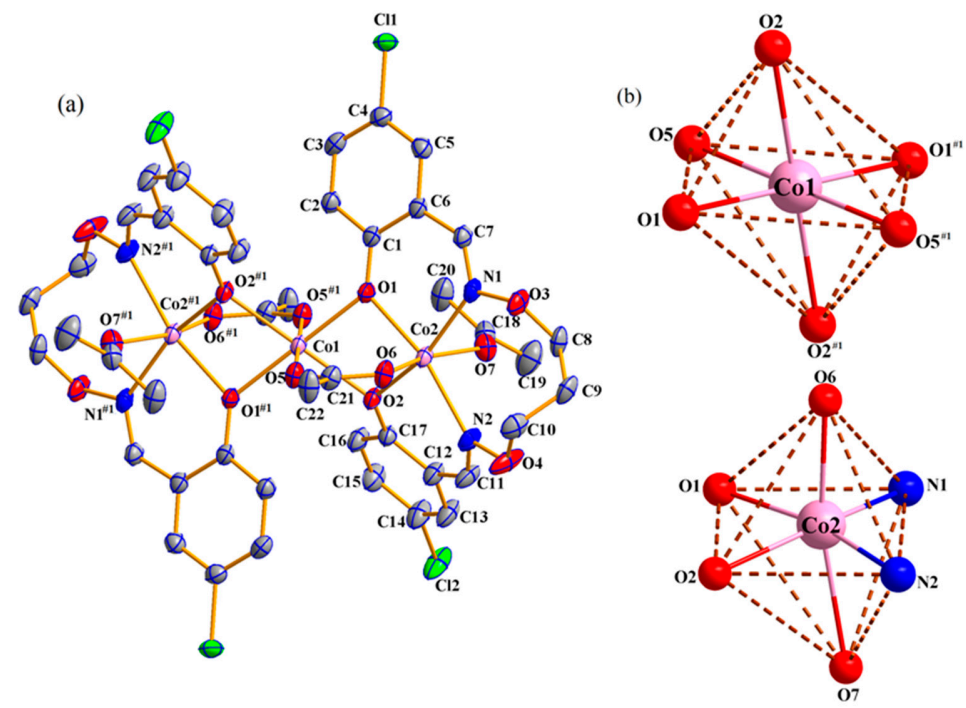

Figure 3. (a) Molecular structure and atom numberings of coordination compound 1 with $30 \%$ probability displacement ellipsoids (hydrogen atoms are omitted for clarity); (b) Coordination polyhedra for $\mathrm{Co}(\mathrm{II})$ atoms of coordination compound $\mathbf{1}$. 
In coordination compound 1 , six pairs of intramolecular hydrogen bond $(\mathrm{C} 2-\mathrm{H} 2 \cdots \mathrm{O} 2, \mathrm{C} 8-\mathrm{H} 8 \mathrm{~B} \cdots \mathrm{O} 7$, $\mathrm{C} 10-\mathrm{H} 10 \mathrm{~B} \cdots \mathrm{O} 3, \mathrm{C} 10-\mathrm{H} 10 \mathrm{~B} \cdots \mathrm{O} 6, \mathrm{C} 16-\mathrm{H} 16 \cdots \mathrm{O} 5$ and $\mathrm{C} 20-\mathrm{H} 20 \mathrm{C} \cdots \mathrm{O} 5)$ [68] interactions involving one phenoxo oxygen, one coordinated acetone, two acetate ions, and alkoxy $O$ atoms in each molecule (Figure 4) and the weak hydrogen bonds existing in the coordination compound $\mathbf{1}$ are described in graph sets (Figure 5) [69], A pair of $\pi \cdots \pi$ interactions (Cg1 $\cdots$ Cg2 (Cg1=C1-C2-C3-C4-C5-C6 and $\mathrm{Cg} 2=\mathrm{C} 12-\mathrm{C} 13-\mathrm{C} 14-\mathrm{C} 15-\mathrm{C} 16-\mathrm{C} 17))$ (Figure 6) were formed [70].

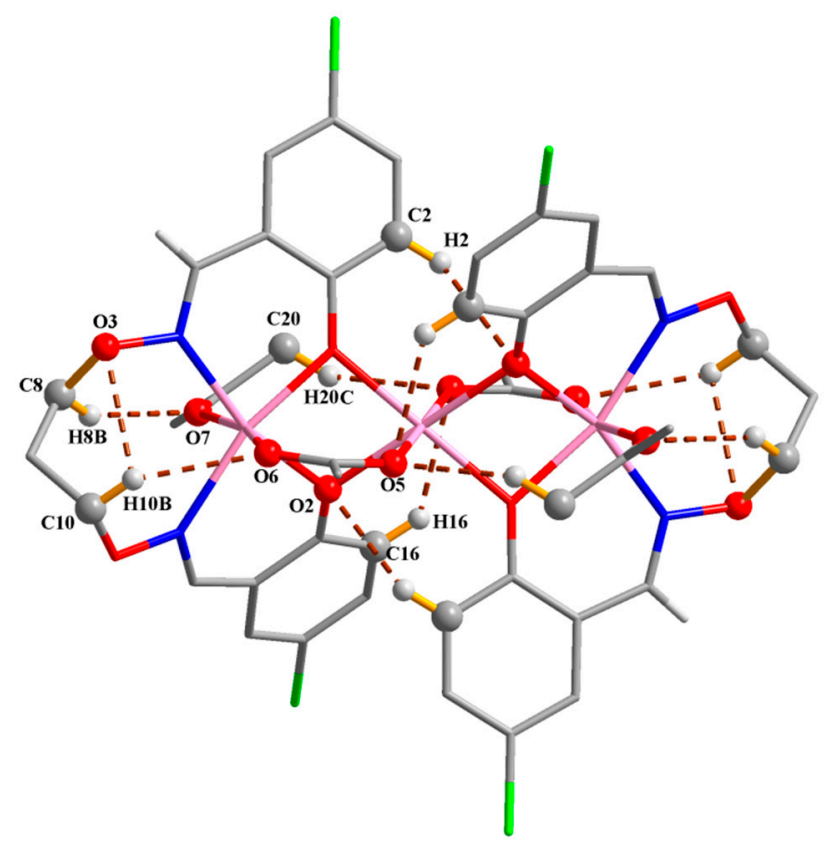

Figure 4. View of the intra-molecular hydrogen bonds of coordination compound $\mathbf{1}$.

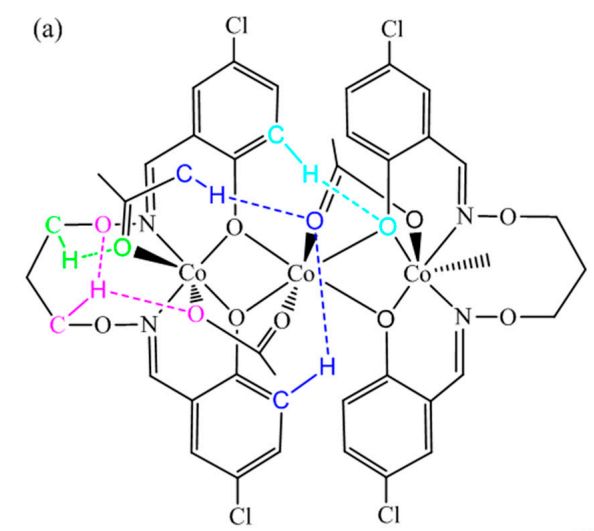<smiles></smiles>

S(5) and S(6)

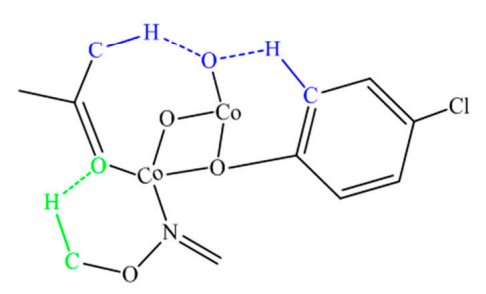

$S(6), S(8)$ and $S(6)$<smiles>CCOc1c(C=N)cc(Cl)cc1POC(C)C</smiles>

Figure 5. (a) Graph set assignments for coordination compound 1; (b) partial enlarged drawing of hydrogen bonds. 


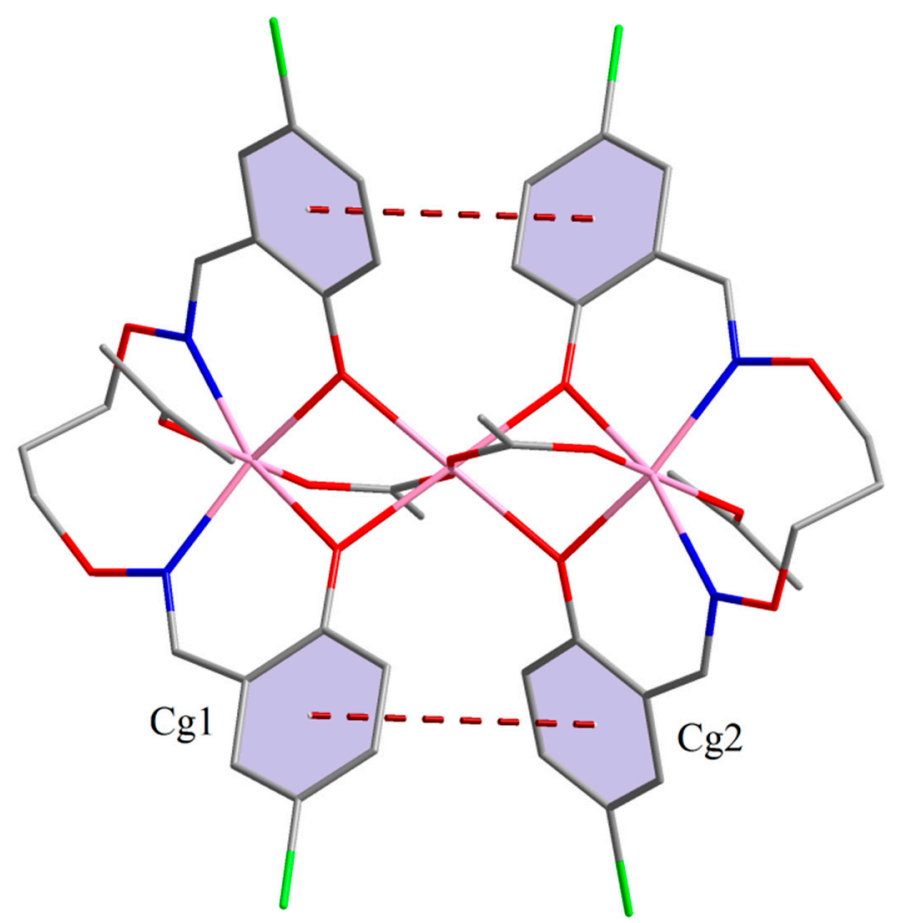

Figure 6. $\pi \cdots \pi$ interactions of coordination compound 1 .

\subsubsection{Crystal Structure of Coordination Compound 2}

The crystal structure of coordination compound $\mathbf{2}$ is given in Figure 7. The crystal structure demonstrates that coordination compound 2 crystallizes in the monoclinic system, space group $P 2_{1} / c$. A mononuclear $\mathrm{Ni}(\mathrm{II})$ coordination compound is formed, with a $\mathrm{Ni1}$ atom occupying the center of symmetry $(1 / 2,1 / 2,1 / 2)$ is related by this center of symmetry. The two $\left(\mathrm{L}^{2}\right)^{2-}$ (symmetry code $\left.\left({ }^{\# 2}\right):-x+1 / 2,-y+1 / 2,-z\right)$ is related by this center of symmetry. Obviously, the desired trior mono-nuclear $\mathrm{Ni}(\mathrm{II})$ coordination compound was not obtained (Scheme 2). The coordination compoundation of the ligand $\mathrm{H}_{2} \mathrm{~L}^{1}$ with $\mathrm{Ni}$ (II) acetate is unstable, giving a new NO bidentate ligand $\left(\mathrm{H}_{2} \mathrm{~L}^{2}\right)$. The formation of the new ligand may be due to the catalysis of $\mathrm{Ni}(\mathrm{II})$ ions resulting in unexpected cleavage of two $\mathrm{N}-\mathrm{O}$ and two $\mathrm{C}-\mathrm{C}$ bonds in $\mathrm{H}_{2} \mathrm{~L}^{1}$. In the $\mathrm{C}=\mathrm{N}$ bond, the electronegativity of the $\mathrm{N}$ atom is higher than the $\mathrm{C}$ atom, so the electron cloud density of $\mathrm{C}$ atom is lower. At the same time, due to the high electronegativity of the $\mathrm{Cl}$ atom, the electron cloud density of the $\mathrm{C}$ atom in the $\mathrm{C}=\mathrm{N}$ bond will be further reduced in this conjugated system, and is positively charged. The electronegativity of the $\mathrm{O}$ atom in the $\mathrm{O}-\mathrm{C}-\mathrm{C}$ bond is high, and will attack the $\mathrm{C}$ atom in the $\mathrm{C}=\mathrm{N}$ bond and form the new ligand $\mathrm{H}_{2} \mathrm{~L}^{1}$. Finally, an unprecedented mono-nuclear $\mathrm{Ni}$ (II) coordination compound is obtained. This phenomenon is observed in the formation of Salamo-type $\mathrm{Cu}$ (II) coordination compounds [71]. However, the catalytic phenomenon of $\mathrm{Ni}$ (II) ions is a first in the previously reported Salamo $\mathrm{Ni}$ (II) coordination compounds. In coordination compound 2, the Ni1 atom has no significant distortion in the $\mathrm{NiO}_{2} \mathrm{~N}_{2}$ planar quadrilateral geometry. It is noteworthy that the angles of $\mathrm{N} 1-\mathrm{Ni1}-\mathrm{N} 1^{\# 3}$ and $\mathrm{O} 1-\mathrm{Ni1}-\mathrm{O} 1^{\# 3}$ are all $180.0^{\circ}$ in coordination compound 2 [72].

\subsection{Fluorescence Properties}

The fluorescence properties of $\mathrm{H}_{2} \mathrm{~L}^{1}$ and coordination compounds 1 and 2 were investigated (Figure 8). The $\mathrm{H}_{2} \mathrm{~L}^{1}$ demonstrates an intense emission peak at ca. $508 \mathrm{~nm}$ upon excitation at $328 \mathrm{~nm}$. Coordination compounds $\mathbf{1}$ and $\mathbf{2}$ demonstrate weak photoluminescence with maximum emission peaks at ca. 516 and $510 \mathrm{~nm}$ upon excitation at $386 \mathrm{~nm}$, respectively, and the absorption peaks are bathochromically-shifted, which could be attributed to LMCT (ligand-to-metal charge transfer) [73,74]. 
Compared with $\mathrm{H}_{2} \mathrm{~L}^{1}$, the emission intensity of coordination compound 2 is reduced, which indicates that the $\mathrm{Ni}(\mathrm{II})$ ions possess the property of fluorescent quenching.

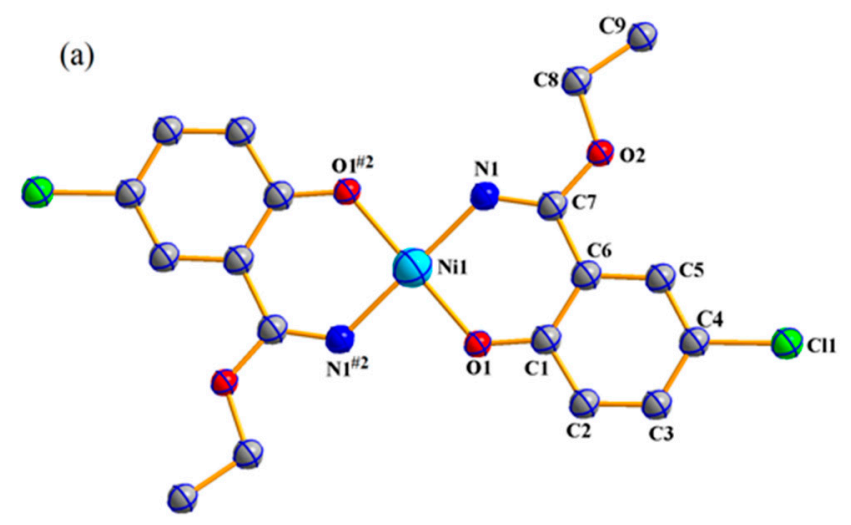

(b)

Figure 7. (a) Molecular structure and atom numberings of coordination compound 2 with $30 \%$ probability displacement ellipsoids (hydrogen atoms are omitted for clarity); (b) Coordination polyhedra for $\mathrm{Ni}(\mathrm{II})$ atoms of coordination compound 2.

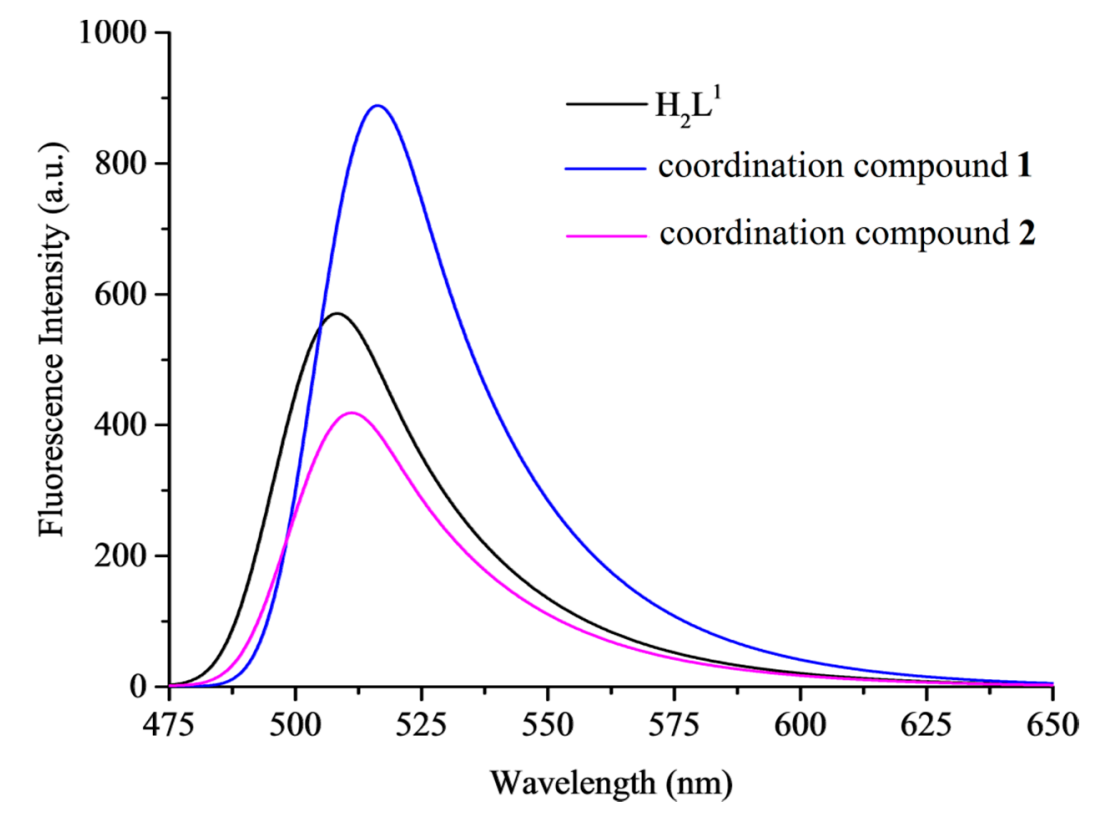

Figure 8. Emission spectra of $\mathrm{H}_{2} \mathrm{~L}^{1}\left(\lambda_{\mathrm{ex}}=328 \mathrm{~nm}\right)$ and its coordination compounds $\mathbf{1}$ and $\mathbf{2}\left(\lambda_{\mathrm{ex}}=386 \mathrm{~nm}\right)$ in $\mathrm{CH}_{3} \mathrm{OH}\left(2.5 \times 10^{-5} \mathrm{M}\right)$.

\subsection{Antimicrobial Activities}

The antimicrobial activities of $\mathrm{H}_{2} \mathrm{~L}^{1}$, cobalt acetate and its coordination compounds $\mathbf{1}$ and 3 were tested against Escherichia coli as Gram-negative bacteria and Staphylococcus aureus as Gram-positive bacteria by a disk diffusion test. With sterile disks impregnated with purified $\mathrm{H}_{2} \mathrm{~L}^{1}$, cobalt acetate, coordination compounds $\mathbf{1}$ and $\mathbf{3}$ were applied to lysogeny broth agar (LB) plates ( $2 \%$ agar). The bacteria inoculum was spread on the surface of the plate, while the impregnated disks were placed near the edge of the plate at a constant distance from the disk for all assays. After eight hours of incubation at $37^{\circ} \mathrm{C}$, the growth-inhibitory influence and diameters of the inhibition zones were mensurated. The discs measuring $5 \mathrm{~mm}$ in diameter were dissolved in dimethyl sulfoxide (DMSO) and soaked in concentrations of $0.35,0.7,1.4,2.8$ and $5.0 \mathrm{mg} \mathrm{mL}^{-1}$. The results were compared to Ampicillin as reference standard with different concentrations. The diameter of inhibition zones of 
$\mathrm{H}_{2} \mathrm{~L}^{1}$, cobalt acetate and coordination compounds $\mathbf{1}$ and $\mathbf{3}$ are shown in Figure 9, the two coordination compounds show more enhanced antimicrobial activities than $\mathrm{H}_{2} \mathrm{~L}^{1}$ and cobalt acetate under the same conditions. $\mathrm{H}_{2} \mathrm{~L}^{1}$ and cobalt acetate also have weak biological activity $[75,76]$. As shown in Figure 9, chelation decreases the polarity of the metal atom mainly because of the partial share of the positive charge of the Co(II) atom with donor groups and possible delocalization of $\pi$-electrons within the whole chelating ring. Further, it enhances the lipophilic character of the central atom. These observations are analogical to earlier reports of biological activities of related Schiff base coordination compounds [77].
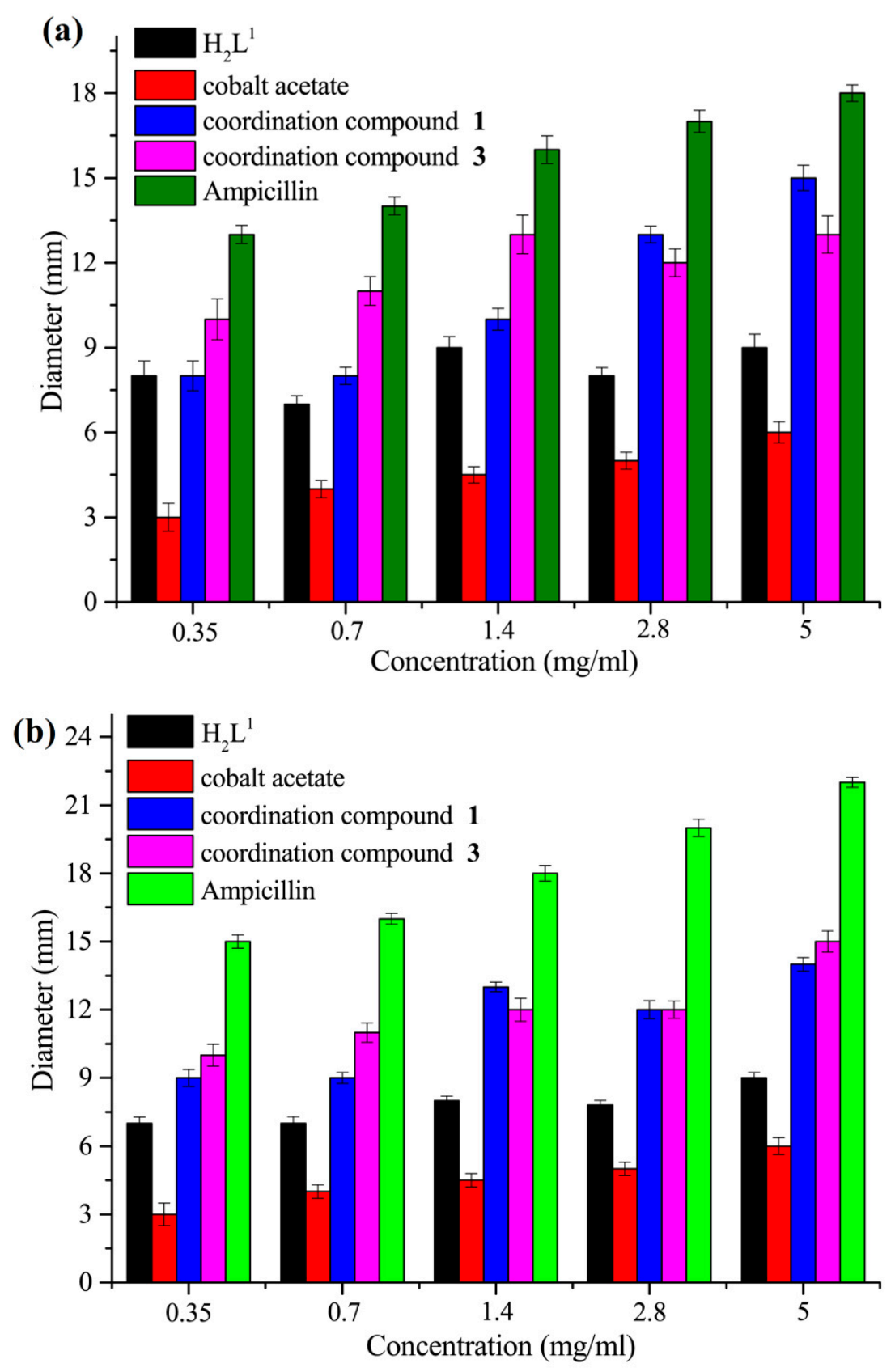

Figure 9. The diameter of inhibition zones of E. coli (a) and S. aureus (b) at different concentrations.

\section{Conclusions}

One trinuclear $\mathrm{Co}(\mathrm{II})$ coordination compound $\mathbf{1}$ and one unprecedented mononuclear $\mathrm{Ni}(\mathrm{II})$ coordination compound 2 were formulated and synthesized. The results show that the Co(II) atoms have no significant distortion in $\mathrm{CoO}_{6}$ or $\mathrm{CoO}_{4} \mathrm{~N}_{2}$ octahedrons in coordination compound 1 . 
Catalysis of $\mathrm{Ni}(\mathrm{II})$ ions gives rise to unexpected cleavage of two $\mathrm{N}-\mathrm{O}$ and two $\mathrm{C}-\mathrm{C}$ bonds in $\mathrm{H}_{2} \mathrm{~L}^{1}$, the coordination compoundation of the ligand $\mathrm{H}_{2} \mathrm{~L}^{1}$ with $\mathrm{Ni}(\mathrm{II})$ acetate is unstable, giving a new $\mathrm{NO}$ bidentate ligand $\left(\mathrm{H}_{2} \mathrm{~L}^{2}\right)$. The desired tri- or mono-nuclear Salamo $\mathrm{Ni}(\mathrm{II})$ coordination compound was not obtained, a novel mono-nuclear $\mathrm{Ni}(\mathrm{II})$ coordination compound $\left[\mathrm{Ni}\left(\mathrm{L}^{2}\right)_{2}\right]$ was however obtained. Interestingly, in coordination compound 2, the $\mathrm{Ni1}$ atom has no significant distortion in the $\mathrm{NiO}_{2} \mathrm{~N}_{2}$ planar quadrilateral geometry. The fluorescence behavior of $\mathrm{H}_{2} \mathrm{~L}^{1}$ and its coordination compounds 1 and 2 were investigated, compared with the ligand $\mathrm{H}_{2} \mathrm{~L}^{1}$ : the emission intensity of coordination compound 2 decreases obviously, which indicates that the $\mathrm{Ni}$ (II) ions possess the quality of fluorescent quenching. Antimicrobial experiments show that coordination compounds $\mathbf{1}$ and $\mathbf{3}$ demonstrate more enhanced antimicrobial activities than Salamo bisoxime ligand $\mathrm{H}_{2} \mathrm{~L}^{1}$ under the same conditions and the ligand possesses a weak biological activity.

Acknowledgments: This work was supported by the National Natural Science Foundation of China (21761018) and the Program for the Excellent Team of Scientific Research in Lanzhou Jiaotong University (201706), which is gratefully acknowledged.

Author Contributions: Wen-Kui Dong and Quan-Peng Kang conceived and designed the experiments; Ling-Zhi Liu performed the experiments; Jian-Chun Ma analyzed the data; Wen-Kui Dong contributed reagents/materials/analysis tools; Xiao-Yan Li wrote the paper.

Conflicts of Interest: The authors declare no competing financial interests.

\section{References}

1. Sun, Y.X.; Zhang, S.T.; Ren, Z.L.; Dong, X.Y.; Wang, L. Synthesis, characterization, and crystal structure of a new supramolecular $\mathrm{Cd}^{\mathrm{II}}$ complex with halogen-substituted salen-type bisoxime. Synth. React. Inorg. Met.-Org. Nano-Met. Chem. 2013, 43, 995-1000. [CrossRef]

2. Chai, L.Q.; Wang, G.; Sun, Y.X.; Dong, W.K.; Zhao, L.; Gao, X.H. Synthesis, crystal structure, and fluorescence of an unexpected dialkoxo-bridged dinuclear copper(II) complex with bis(salen)-type tetraoxime. J. Coord. Chem. 2012, 65, 1621-1631. [CrossRef]

3. Song, X.Q.; Liu, P.P.; Liu, Y.A.; Zhou, J.J.; Wang, X.L. Two dodecanuclear heterometallic $\left[Z_{6} \operatorname{Ln}_{6}\right]$ clusters constructed by a multidentate salicylamide salen-like ligand: Synthesis, structure, luminescence and magnetic properties. Dalton Trans. 2016, 45, 8154-8163. [CrossRef] [PubMed]

4. Li, X.Y.; Chen, L.; Gao, L.; Zhang, Y.; Akogun, S.F.; Dong, W.K. Syntheses, crystal structures and catalytic activities of two solvent-induced homotrinuclear Co(II) complexes with a naphthalenediol-based bis(Salamo)-type tetraoxime ligand. RSC Adv. 2017, 7, 35905-35916. [CrossRef]

5. Haak, R.M.; Decortes, A.; Escudero, E.C.; Belmonte, M.M.; Martin, E.; Buchholz, J.B.; Kleij, A.W. Shape-persistent octanuclear zinc salen clusters: Synthesis, characterization, and catalysis. Inorg. Chem. 2011, 50, 7934-7936. [CrossRef] [PubMed]

6. Wu, H.L.; Bai, Y.C.; Zhang, Y.H.; Pan, G.L.; Kong, J.; Shi, F.; Wang, X.L. Two lanthanide(III) complexes based on the schiff base $N, N$-Bis(salicylidene)-1,5-diamino-3-oxapentane: Synthesis, characterization, DNA-binding properties, and antioxidation. Z. Anorg. Allg. Chem. 2014, 640, 2062-2071. [CrossRef]

7. Chen, C.Y.; Zhang, J.W.; Zhang, Y.H.; Yang, Z.H.; Wu, H.L. Gadolinium(III) and dysprosium(III) complexes with a Schiff base bis( $N$-salicylidene)-3-oxapentane-1,5-diamine: Synthesis, characterization, antioxidation, and DNA-binding studies. J. Coord. Chem. 2015, 68, 1054-1071. [CrossRef]

8. Wu, H.L.; Pan, G.L.; Wang, H.; Wang, X.L.; Bai, Y.C.; Zhang, Y.H. Study on synthesis, crystal structure, antioxidant and DNA-binding of mono-, di- and poly-nuclear lanthanides complexes with bis(N-salicylidene)-3-oxapentane-1,5-diamine. J. Photochem. Photobiol. B Biol. 2014, 135, 33-43. [CrossRef] [PubMed]

9. Wu, H.L.; Wang, C.P.; Wang, F.; Peng, H.P.; Zhang, H.; Bai, Y.C. A new manganese(III) complex from bis(5-methylsalicylaldehyde)-3-oxapentane-1,5-diamine: Synthesis, characterization, antioxidant activity and luminescence. J. Chin. Chem. Soc. 2015, 62, 1028-1034. [CrossRef]

10. Wu, H.L.; Bai, Y.C.; Zhang, Y.H.; Li, Z.; Wu, M.C.; Chen, C.Y.; Zhang, J.W. Synthesis, crystal structure, antioxidation and DNA-binding properties of a dinuclear copper(II) complex with bis(N-salicylidene)-3-oxapentane-1, 5-diamine. J. Coord. Chem. 2014, 67, 3054-3066. [CrossRef] 
11. Chai, L.Q.; Tang, L.J.; Chen, L.C.; Huang, J.J. Structural, spectral, electrochemical and DFT studies of two mononuclear manganese(II) and zinc(II) complexes. Polyhedron 2017, 122, 228-240. [CrossRef]

12. Dong, Y.J.; Li, X.L.; Zhang, Y.; Dong, W.K. A highly selective visual and fluorescent sensor for $\mathrm{Pb}^{2+}$ and $\mathrm{Zn}^{2+}$ and crystal structure of $\mathrm{Cu}^{2+}$ complex based-on a novel single-armed Salamo-type bisoxime. Supramol. Chem. 2017, 29, 518-527. [CrossRef]

13. Dong, W.K.; Li, X.L.; Wang, L.; Zhang, Y.; Ding, Y.J. A new application of Salamo-type bisoximes: As a relay-sensor for $\mathrm{Zn}^{2+} / \mathrm{Cu}^{2+}$ and its novel complexes for successive sensing of $\mathrm{H}^{+} / \mathrm{OH}^{-}$. Sens. Actuators $B$ 2016, 229, 370-378. [CrossRef]

14. Wang, B.J.; Dong, W.K.; Zhang, Y.; Akogun, S.F. A novel relay-sensor for highly sensitive and selective detection of $\mathrm{Zn}^{2+} / \mathrm{Pic}^{-}$and fluorescence on/off switch response of $\mathrm{H}^{+} / \mathrm{OH}^{-}$. Sens. Actuators B 2017, 247, 254-264. [CrossRef]

15. Wang, F.; Gao, L.; Zhao, Q.; Zhang, Y.; Dong, W.K.; Ding, Y.J. A highly selective fluorescent chemosensor for $\mathrm{CN}^{-}$based on a novel bis(salamo)-type tetraoxime ligand. Spectrochim. Acta Part A 2018, 190, 111-115. [CrossRef] [PubMed]

16. Dong, W.K.; Akogun, S.F.; Zhang, Y.; Sun, Y.X.; Dong, X.Y. A reversible “turn-on” fluorescent sensor for selective detection of $\mathrm{Zn}^{2+}$. Sens. Actuators B 2017, 238, 723-734. [CrossRef]

17. Wang, L.; Ma, J.C.; Dong, W.K.; Zhu, L.C.; Zhang, Y. A novel Self-assembled nickel(II)-cerium(III) heterotetranuclear dimer constructed from $\mathrm{N}_{2} \mathrm{O}_{2}$-type bisoxime and terephthalic acid: Synthesis, structure and photophysical properties. Z. Anorg. Allg. Chem. 2016, 642, 834-839. [CrossRef]

18. Chai, L.Q.; Huang, J.J.; Zhang, J.Y.; Li, Y.X. Two 1-D and 2-D cobalt(II) complexes: Synthesis, crystal structures, spectroscopic and electrochemical properties. J. Coord. Chem. 2015, 68, 1224-1237. [CrossRef]

19. Zheng, S.S.; Dong, W.K.; Zhang, Y.; Chen, L.; Ding, Y.J. Four Salamo-type 3d-4f hetero-bimetallic $\left[\mathrm{Zn}^{\mathrm{II}} \mathrm{Ln}^{\mathrm{III}}\right]$ complexes: Syntheses, crystal structures, and luminescent and magnetic properties. New J. Chem. 2017, 41, 4966-4973. [CrossRef]

20. Dong, W.K.; Ma, J.C.; Zhu, L.C.; Zhang, Y. Self-assembled zinc(II)-lanthanide(III) heteromultinuclear complexes constructed from 3-MeOsalamo ligand: Syntheses, structures and luminescent properties. Cryst. Growth Des. 2016, 16, 6903-6914. [CrossRef]

21. Liu, Y.A.; Wang, C.Y.; Zhang, M.; Song, X.Q. Structures and magnetic properties of cyclic heterometallic tetranuclear clusters. Polyhedron 2017, 127, 278-286. [CrossRef]

22. Song, X.Q.; Liu, P.P.; Xiao, Z.R.; Li, X.; Liu, Y.A. Four polynuclear complexes based on a versatile salicylamide salen-like ligand: Synthesis, structural variations and magnetic properties. Inorg. Chim. Acta 2015, 438, 232-244. [CrossRef]

23. Liu, P.P.; Wang, C.Y.; Zhang, M.; Song, X.Q. Pentanuclear sandwich-type $\mathrm{Zn}^{\mathrm{II}}$-Ln ${ }^{\mathrm{III}}$ clusters based on a new Salen-like salicylamide ligand: Structure, near-infrared emission and magnetic properties. Polyhedron 2017, 129, 133-140. [CrossRef]

24. Liu, P.P.; Sheng, L.; Song, X.Q.; Xu, W.Y.; Liu, Y.A. Synthesis, structure and magnetic properties of a new one dimensional manganese coordination polymer constructed by a new asymmetrical ligand. Inorg. Chim. Acta 2015, 434, 252-257. [CrossRef]

25. Dong, X.Y.; Akogun, S.F.; Zhou, W.M.; Dong, W.K. Tetranuclear Zn(II) complex based on an asymmetrical Salamo-type chelating ligand: Synthesis, structural characterization, and fluorescence property. J. Chin. Chem. Soc. 2017, 64, 412-419. [CrossRef]

26. Song, X.Q.; Cheng, G.Q.; Liu, Y.A. Enhanced $\mathrm{Tb}(\mathrm{III})$ luminescence by $\mathrm{d}^{10}$ transition metal coordination. Inorg. Chim. Acta 2016, 450, 386-394. [CrossRef]

27. Dong, Y.J.; Ma, J.C.; Zhu, L.C.; Dong, W.K.; Zhang, Y. Four 3d-4f heteromultinuclear zinc(II)-lanthanide(III) complexes constructed from a distinct hexadentate $\mathrm{N}_{2} \mathrm{O}_{2}$-type ligand: Syntheses, structures and photophysical properties. J. Coord. Chem. 2017, 70, 103-115. [CrossRef]

28. Dong, W.K.; Zheng, S.S.; Zhang, J.T.; Zhang, Y.; Sun, Y.X. Luminescent properties of heterotrinuclear 3d-4f complexes constructed from a naphthalenediol-based acyclic bis(salamo)-type ligand. Spectrochim. Acta Part A 2017, 184, 141-150. [CrossRef] [PubMed]

29. Hao, J.; Li, L.L.; Zhang, J.T.; Akogun, S.F.; Wang, L.; Dong, W.K. Four homo- and hetero-bismetallic 3d/3d-2s complexes constructed from a naphthalenediol-based acyclic bis(salamo)-type tetraoxime ligand. Polyhedron 2017, 134, 1-10. [CrossRef] 
30. Gao, L.; Wang, F.; Zhao, Q.; Zhang, Y.; Dong, W.K. Mononuclear Zn(II) and trinuclear Ni(II) complexes derived from a coumarin-containing $\mathrm{N}_{2} \mathrm{O}_{2}$ ligand: Syntheses, crystal structures and fluorescence properties. Polyhedron 2018, 139, 7-16. [CrossRef]

31. Akine, S.; Taniguchi, T.; Dong, W.K.; Masubuchi, S.; Nabeshima, T. Oxime-based salen-type tetradentate ligands with high stability against imine metathesis reaction. J. Org. Chem. 2005, 70, 1704-1711. [CrossRef] [PubMed]

32. Wang, L.; Li, X.Y.; Zhao, Q.; Li, L.H.; Dong, W.K. Fluorescence properties of heterotrinuclear Zn(II)-M(II) $(\mathrm{M}=\mathrm{Ca}$, Sr and Ba) bis(salamo)-type complexes. RSC Adv. 2017, 7, 48730-48737. [CrossRef]

33. Wang, P.; Zhao, L. An infinite 2D supramolecular cobalt(II) complex based on an asymmetric Salamo-type ligand: Synthesis, crystal structure, and spectral properties. Synth. React. Inorg. Met.-Org. Nano-Met. Chem. 2016, 46, 1095-1101. [CrossRef]

34. Chai, L.Q.; Zhang, K.Y.; Tang, L.J.; Zhang, J.Y.; Zhang, H.S. Two mono- and dinuclear Ni(II) complexes constructed from quinazoline-type ligands: Synthesis, X-ray structures, spectroscopic, electrochemical, thermal, and antimicrobial studies. Polyhedron 2017, 130, 100-107. [CrossRef]

35. Akine, S.; Taniguchi, T.; Nabeshima, T. Novel synthetic approach to trinuclear 3d-4f complexes: Specific exchange of the central metal of a trinuclear zinc(II) complex of a tetraoxime ligand with a lanthanide(III) ion. Angew. Chem. Int. Ed. 2002, 41, 4670-4673. [CrossRef] [PubMed]

36. Dong, W.K.; Duan, J.G.; Guan, Y.H.; Shi, J.Y.; Zhao, C.Y. Synthesis, crystal structure and spectroscopic behaviors of $\mathrm{Co}(\mathrm{II})$ and $\mathrm{Cu}(\mathrm{II})$ complexes with Salen-type bisoxime ligands. Inorg. Chim. Acta 2009, 362, 1129-1134. [CrossRef]

37. Dong, W.K.; Sun, Y.X.; Zhao, C.Y.; Dong, X.Y.; Xu, L. Synthesis, structure and properties of supramolecular $\mathrm{Mn}^{\mathrm{II}}, \mathrm{Co}^{\mathrm{II}}, \mathrm{Ni}^{\mathrm{II}}$ and $\mathrm{Zn}^{\mathrm{II}}$ complexes containing Salen-type bisoxime ligands. Polyhedron 2010, 29, 2087-2097. [CrossRef]

38. Dong, W.K.; Duan, J.G. A trinuclear Ni(II) cluster with two significantly different configurations in the solid state. J. Coord. Chem. 2008, 61, 781-788. [CrossRef]

39. Sun, Y.X.; Zhang, Y.J.; Meng, W.S.; Li, X.R.; Lu, R.E. Synthesis and crystal structure of new nickel(II) complex with Salen-type bisoxime ligand. Asian J. Chem. 2014, 26, 416-418.

40. Gao, X.H.; Dong, X.Y.; Li, L.; Sun, Y.X.; Dong, W.K. Crystal structure of bis[(3,3'-dimethoxy-2,2'-1,3-propylene) dioxybis(nitrilomethylidyne)diphenolato]-bis(acetato- $\mathrm{O}^{1}, \mathrm{O}^{2}$ )-bis(ethanol-O)trinickel(II)-ethanol-acetone (1:2:1.06), $\mathrm{Ni}_{3}\left(\mathrm{C}_{19} \mathrm{H}_{20} \mathrm{~N}_{2} \mathrm{O}_{6}\right)_{2}\left(\mathrm{C}_{2} \mathrm{H}_{5} \mathrm{OH}\right)_{2}\left(\mathrm{C}_{2} \mathrm{H}_{3} \mathrm{O}_{2}\right)_{2} \cdot 2 \mathrm{C}_{2} \mathrm{H}_{5} \mathrm{OH} \cdot 1.06 \mathrm{C}_{3} \mathrm{H}_{6} \mathrm{O}$. Z. Kristallogr. NCS 2011, 226, 138-140. [CrossRef]

41. Dong, W.K.; Duan, J.G.; Xu, L.; Sun, Y.X.; Shi, J.Y.; Tang, X.L. Synthesis, characterization and crystal structure of a trinuclear $\mathrm{Ni}(\mathrm{II})$ cluster. Chin. J. Inorg. Chem. 2009, 25, 522-527.

42. Dong, W.K.; Li, L.; Sun, Y.X.; Tong, J.F.; Wu, J.C. Syntheses, structures and properties of 3,3'-dimethoxy-2,2'-[(1,3-propylene)dioxybis(nitrilomethylidyne)]diphenol and its $\mathrm{Ni}(\mathrm{II})$ cluster. Synth. React. Inorg. Met.-Org. Nano-Met. Chem. 2012, 41, 716-724. [CrossRef]

43. Dong, W.K.; Li, L.; Sun, Y.X.; Tong, J.F.; Wu, J.C. Supramolecular cobalt(II) complexes: Syntheses, crystal structures and solvent effects. Transit. Met. Chem. 2010, 35, 787-794. [CrossRef]

44. Dong, W.K.; Yao, J.; Sun, Y.X. Synthesis, characterization, and crystal structure of a tri-nuclear cobalt(II) cluster. Synth. React. Inorg. Met.-Org. Nano-Met. Chem. 2011, 41, 177-181.

45. Dong, W.K.; Shi, J.Y.; Zhong, J.K.; Sun, Y.X.; Duan, J.G. Synthesis and structural characterization of a novel tricobalt cluster with 4,4'-dichloro-2,2'-[(1,3-propylene)dioxybis(nitrilomethylidyne)]diphenol. Struct. Chem. 2008, 19, 95-99. [CrossRef]

46. Dong, W.K.; Duan, J.G.; Liu, G.L.; Shi, J.Y. Synthesis, characterization and crystal structure of a novel tri-nuclear $\mathrm{Ni}(\mathrm{II})$ cluster bearing tetra- $\mu$-phenoxo and di- $\mu$-acetato bridges. Synth. React. Inorg. Met.-Org. Nano-Met. Chem. 2007, 37, 627-631.

47. Dong, W.K.; Ma, J.C.; Zhu, L.C.; Zhang, Y.; Li, X.L. Four new nickel(II) complexes based on an asymmetric Salamo-type ligand: Synthesis, structure, solvent effect and electrochemical property. Inorg. Chim. Acta 2016, 445, 140-148. [CrossRef]

48. Dong, W.K.; Shi, J.Y.; Zhong, J.K.; Tian, Y.Q.; Duan, J.G. Synthesis, crystal structure and infrared spectral analysis for a trinuclear nickel(II) cluster. Chin. J. Inorg. Chem. 2008, 24, 10-14. 
49. Dong, W.K.; Chen, X.; Sun, Y.X.; Yang, Y.H.; Zhao, L.; Xu, L.; Yu, T.Z. Synthesis, structure and spectroscopic properties of two new trinuclear nickel(II) clusters possessing solvent effect. Spectrochim. Acta Part A 2009, 74, 719-725. [CrossRef] [PubMed]

50. Dong, W.K.; Shi, J.Y.; Xu, L.; Zhong, J.K.; Duan, J.G.; Zhang, Y.P. Synthesis, crystal structure and infrared spectra of $\mathrm{Cu}$ (II) and $\mathrm{Co}(\mathrm{II})$ complexes with 4,4'-dichloro-2,2'-[ethylene dioxybis(nitrilomethylidyne)]diphenol. Appl. Organometal. Chem. 2008, 22, 89-96. [CrossRef]

51. Sheldrick, G.M. SHELXS 97, Program for Crystal Structure Solution; University of Göttingen: Göttingen, Germany, 1997.

52. Sheldrick, G.M. SHELXL 97, Program for Crystal Structure Refinement; University of Göttingen: Göttingen, Germany, 1997.

53. Xu, L.; Zhu, L.C.; Ma, J.C.; Zhang, Y.; Zhang, J.; Dong, W.K. Syntheses, structures and spectral properties of mononuclear $\mathrm{Cu}^{\mathrm{II}}$ and dimeric $\mathrm{Zn}^{\mathrm{II}}$ complexes based on an asymmetric Salamo-type $\mathrm{N}_{2} \mathrm{O}_{2}$ ligand. Z. Anorg. Allg. Chem. 2015, 641, 2520-2524. [CrossRef]

54. Zhang, H.; Dong, W.K.; Zhang, Y.; Akogun, S.F. Naphthalenediol-based bis(Salamo)-type homo- and heterotrinuclear cobalt(II) complexes: Syntheses, structures and magnetic properties. Polyhedron 2017, 133, 279-293. [CrossRef]

55. Yang, Y.H.; Hao, J.; Dong, Y.J.; Wang, G.; Dong, W.K. Two znic(II) complexes constructed from a bis(salamo)-type tetraoxime ligand: Syntheses, crystal structures and luminescence properties. Chin. J. Inorg. Chem. 2017, 33, 1280-1292.

56. Sun, Y.X.; Xu, L.; Zhao, T.H.; Liu, S.H.; Liu, G.H.; Dong, X.T. Synthesis and crystal structure of a 3D supramolecular copper(II) complex with 1-(3-\{[(E)-3-bromo-5-chloro-2-hydroxybenzylidene]amino\}phenyl) ethanone oxime. Synth. React. Inorg. Met.-Org. Nano-Met. Chem. 2013, 43, 509-513. [CrossRef]

57. Wang, L.; Hao, J.; Zhai, L.X.; Zhang, Y.; Dong, W.K. Synthesis, crystal structure, luminescence, electrochemical and antimicrobial properties of bis(salamo)-based Co(II) complex. Crystals 2017, 7, 277. [CrossRef]

58. Zhao, L.; Dang, X.T.; Chen, Q.; Zhao, J.X.; Wang, L. Synthesis, Crystal Structure and Spectral Properties of a 2D Supramolecular Copper(II) Complex With 1-(4-\{[(E)-3-ethoxyl-2-hydroxybenzylidene]amino\}phenyl)ethanone Oxime. Synth. React. Inorg. Met.-Org. Nano-Met. Chem. 2013, 43, 1241-1246. [CrossRef]

59. Dong, X.Y.; Gao, L.; Wang, F.; Zhang, Y.; Dong, W.K. Tri- and Mono-Nuclear Zinc(II) Complexes Based on Half- and Mono-Salamo Chelating Ligands. Crystals 2017, 7, 267. [CrossRef]

60. Wang, P.; Zhao, L. Synthesis and crystal structure of supramolecular copper(II) complex based on $\mathrm{N}_{2} \mathrm{O}_{2}$ coordination Sphere. Asian J. Chem. 2015, 4, 1424-1426. [CrossRef]

61. Dong, X.Y.; Kang, Q.P.; Jin, B.X.; Dong, W.K. A dinuclear nickel(II) complex derived from an asymmetric Salamo-type $\mathrm{N}_{2} \mathrm{O}_{2}$ chelate ligand: Synthesis, structure and optical properties. Z. Naturforsch. 2017, 72, 415-420. [CrossRef]

62. Sun, Y.X.; Gao, X.H. Synthesis, characterization, and crystal structure of a new $\mathrm{Cu}^{\mathrm{II}}$ complex with salen-type ligand. Synth. React. Inorg. Met.-Org. Nano-Met. Chem. 2011, 41, 973-978. [CrossRef]

63. Li, G.; Hao, J.; Liu, L.Z.; Zhou, W.M.; Dong, W.K. Syntheses, crystal structures and thermal behaviors of two supramolecular salamo-type cobalt(II) and zinc(II) complexes. Crystals 2017, 7, 217.

64. Wang, P.; Zhao, L. Synthesis, structure and spectroscopic properties of the trinuclear cobalt(II) and nickel(II) complexes based on 2-hydroxynaphthaldehyde and bis(aminooxy)alkane. Spectrochim. Acta Part A 2015, 135, 342-350. [CrossRef] [PubMed]

65. Ma, J.C.; Dong, X.Y.; Dong, W.K.; Zhang, Y.; Zhu, L.C.; Zhang, J.T. An unexpected dinuclear Cu(II) complex with a bis(Salamo) chelating ligand: Synthesis, crystal structure, and photophysical properties. J. Coord. Chem. 2016, 69, 149-159. [CrossRef]

66. Dong, X.Y.; Li, X.Y.; Liu, L.Z.; Zhang, H.; Ding, Y.J.; Dong, W.K. Tri- and hexanuclear heterometallic $\mathrm{Ni}(\mathrm{II})-\mathrm{M}(\mathrm{II})(\mathrm{M}=\mathrm{Ca}$, Sr and Ba) bis(salamo)-type complexes: Synthesis, structure and fluorescence properties. RSC Adv. 2017, 7, 48394-48403. [CrossRef]

67. Sun, Y.X.; Wang, L.; Dong, X.Y.; Ren, Z.L.; Meng, W.S. Synthesis, characterization, and crystal structure of a supramolecular $\mathrm{Co}^{\mathrm{II}}$ complex containing Salen-type bisoxime. Synth. React. Inorg. Met.-Org. Nano-Met. Chem. 2013, 43, 599-603. [CrossRef]

68. Tao, C.H.; Ma, J.C.; Zhu, L.C.; Zhang, Y.; Dong, W.K. Heterobimetallic 3d-4f Zn(II)-Ln(III) (Ln=Sm, Eu, $\mathrm{Tb}$ and $\mathrm{Dy}$ ) complexes with a $\mathrm{N}_{2} \mathrm{O}_{4}$ bisoxime chelate ligand and a simple auxiliary ligand Py: Syntheses, structures and luminescence properties. Polyhedron 2017, 128, 38-45. [CrossRef] 
69. Bernstein, J.; Davis, R.E.; Shimoni, L.; Chang, N.L. Patterns in hydrogen bonding: Functionality and graph set analysis in crystals. Angew. Chem. Int. Ed. Engl. 1995, 34, 1555-1573. [CrossRef]

70. Kruszynski, R.; Sierański, T. Can stacking interactions exist beyond the commonly accepted limits? Cryst. Growth Des. 2016, 16, 587-595. [CrossRef]

71. Chen, L.; Dong, W.K.; Zhang, H.; Zhang, Y.; Sun, Y.X. Structural variation and luminescence properties of triand dinuclear $\mathrm{Cu}^{\mathrm{II}}$ and $\mathrm{Zn}{ }^{\mathrm{II}}$ complexes constructed from a naphthalenediol-based bis(Salamo)-type ligand. Cryst. Growth Des. 2017, 17, 3636-3648. [CrossRef]

72. Chai, L.Q.; Liu, G.; Zhang, Y.L.; Huang, J.J.; Tong, J.F. Synthesis, crystal structure, fluorescence, electrochemical property, and SOD-like activity of an unexpected nickel(II) complex with a quinazoline-type ligand. J. Coord. Chem. 2013, 66, 3926-3938. [CrossRef]

73. Dong, Y.J.; Dong, X.Y.; Dong, W.K.; Zhang, Y.; Zhang, L.S. Three asymmetric Salamo-type copper(II) and cobalt(II) complexes: Syntheses, structures, fluorescent properties. Polyhedron 2017, 123, 305-315. [CrossRef]

74. Song, X.Q.; Peng, Y.J.; Chen, G.Q.; Wang, X.R.; Liu, P.P.; Xu, W.Y. Substituted group-directed assembly of $\mathrm{Zn}(\mathrm{II})$ coordination complexes based on two new structural related pyrazolone based Salen ligands: Syntheses, structures and fluorescence properties. Inorg. Chim. Acta 2015, 427, 13-21. [CrossRef]

75. Wu, H.L.; Bai, Y.; Yuan, J.K.; Wang, H.; Pan, G.L.; Fan, X.Y.; Kong, J. A zinc(II) complex with tris(2-(N-methyl)benzimidazlylmethyl)amine and salicylate: Synthesis, crystal structure, and DNA-binding. J. Coord. Chem. 2012, 65, 2839-2851. [CrossRef]

76. Wu, H.L.; Pan, G.L.; Bai, Y.C.; Wang, H.; Kong, J. Synthesis, structure, antioxidation, and DNA-bindingstudies of a binuclear ytterbium(III) complex with bis(N-salicylidene)-3-oxapentane-1,5-diamine. Res. Chem. Intermed. 2015, 41, 3375-3388. [CrossRef]

77. Wu, H.L.; Pan, G.L.; Bai, Y.C.; Wang, H.; Kong, J.; Shi, F.; Zhang, Y.H.; Wang, X.L. Preparation, structure, DNA-binding properties, and antioxidant activities of a homodinuclear erbium(III) complex with a pentadentate Schiff base ligand. J. Chem. Res. 2014, 38, 211-217. [CrossRef]

(C) 2018 by the authors. Licensee MDPI, Basel, Switzerland. This article is an open access article distributed under the terms and conditions of the Creative Commons Attribution (CC BY) license (http:// creativecommons.org/licenses/by/4.0/). 